\title{
Significant marine-ice accumulation in the ablation zone beneath an Antarctic ice shelf
}

\author{
A. Khazendar, ${ }^{1}$ J.-L. Tison, ${ }^{1}$ B. Stenni,${ }^{2}$ M. Dini,${ }^{2}$ A. Bondesan ${ }^{3}$ \\ ${ }^{1}$ Département des Sciences de la Terre et de l'Environnement, Faculté des Sciences, CP 160/03, \\ Université Libre de Bruxelles, B-1050 Brussels, Belgium \\ ${ }^{2}$ Laboratorio di Geochimica Isotopica, Università di Trieste, I-34127 Trieste, Italy \\ ${ }^{3}$ Dipartimento di Geografia, Università di Padova, Via del Santo 26, I-35127 Padua, Italy
}

\begin{abstract}
High-resolution crystallographic, salinity and isotopic analyses of a $45 \mathrm{~m}$ ice core reveal the presence of a thick layer of marine ice near the grounding line of the Nansen Ice Shelf, Antarctica. The anomalous formation of marine ice in a zone assumed to be the site of active basal melting leads us to propose the hypothesis of large basal crevasses as a favorable environment for important marine-ice accretion. This hitherto unexplored possibility is supported by the overall field configuration and by the discrepancy in some ice properties between this core and the marine-ice sections of previous drilling projects. These findings could have important implications for the general stability of ice shelves and their disintegration processes. The specific properties of this core reveal that marine ice is post-genetically deformed.
\end{abstract}

\section{FRAMEWORK}

The three-decade-old quest to recover ice samples from the interface zone between an ice shelf and the ocean has led investigators down several paths. Work was first done on shallower and thus more accessible ice tongues. The objective of earlier efforts was to demonstrate that sea water must be directly freezing on to the base of ice tongues due to upward heat conduction through the ice, forming congelation ice. Gow and Epstein (1972) provided the first conclusive verification of this assumption. Their work was based on ice cores up to $13 \mathrm{~m}$ deep that had been drilled in the Koettlitz Ice Tongue, Antarctica. The same process, but on a much larger scale, was shown to take place beneath the Ross Ice Shelf (Zotikov and others, 1980) where the bottom-most $6 \mathrm{~m}$ of a $416 \mathrm{~m}$ ice core were composed of frozen sea water. The estimated average freezing rate at this location was inferred by Zotikov and others (1980) to be $2 \mathrm{~cm} \mathrm{a}^{-1}$, which was in good agreement with what Robin (1979) had already theoretically suggested for the Ross Ice Shelf.

Another access to interface ice was identified when Kipfstuhl and others (1992) and then Warren and others (1993) established the basal ice-shelf origin of green icebergs. The latter authors did not hypothesize on the formation mechanism of their green iceberg ice, but they did suggest the possibility that it had accreted at the base of the Amery Ice Shelf. This shelf was earlier the site of a $315 \mathrm{~m}$ deep coring project of which the preliminary results were presented by Morgan (1972). The lowermost $45 \mathrm{~m}$ of this core, known as Gl, were composed of what Morgan (1972) at the time considered to be sea-water ice. However, the slow rate of this conduction-driven process made it inadequate to explain such thick accumulations of basal ice. Hence, a second mechanism was introduced when Robin (1979) linked for the first time the formation of basal ice at Gl with water circulation patterns in the sub-ice-shelf cavity. The process was theoretically elaborated by Lewis and Perkin (1986) through their ice-pump model by which ice is melted at depth and deposited higher in the water column due to the freezing-point dependence on pressure. Later, Engelhardt and Determann (1987) explained how frazil-ice crystals would form in thermohaline circulation and subsequently accrete at the bottom of an ice shelf and consolidate. Modeling of melting and accretion processes at the iceshelf/ocean interface has been further improved in recent years by several authors including Hellmer and Jacobs (1992), Determann and Gerdes (1994), Bombosch and Jenkins (1995) and Jenkins and Bombosch (1995).

The number of available marine-ice samples and cores still remains limited. This could be explained in part by the relatively recent interest in the subject. Then there are the difficulties associated with the two possible sources of basal marine-ice samples. Green icebergs are rarely found in Nature, for the reasons discussed by Warren and others (1993) and Grosfeld and others (1998). On the other hand, drilling for marine ice at the bottom of ice shelves is confronted with the obvious necessity of having to penetrate hundreds of meters of meteoric ice. Other than at Gl, bottom-ice accretion has also been found to constitute the lower $62 \mathrm{~m}$ of the $215 \mathrm{~m}$ core drilled in the Filchner-Ronne Ice Shelf at site B13 (Oerter and others, 1992). Another 320 m core recovered further upstream from the same ice shelf at site $\mathrm{B} 15$ revealed the presence of a $167 \mathrm{~m}$ thick accretion layer at the bottom (Oerter and others, 1994). Layers of solid ice formed below meteoric ice at the bottom of ice shelves are now known by most authors as marine ice (Oerter and others, 1992) and we follow this terminology.

As part of the 1995-96 Belgo-Italian collaboration 
program, a $45 \mathrm{~m}$ ice core was drilled out of the Nansen Ice Shelf (NIS), which is misleadingly identified as an ice sheet on official maps. The NIS core is comparable in length with the marine-ice sections of both the $\mathrm{Gl}$ and B13 cores. We present here the results of high-resolution multiparametric measurements showing that the properties of the entire core correspond to those of marine ice. We believe that this is the first time that a core of marine ice with a formation site so relatively near to the grounding line has been directly collected from the surface of an ice shelf. More importantly, the core's proximity to the grounding line and its specific ice properties prompt us to consider and propose in this work the accretion of marine ice in basal crevasses opening where meteoric ice goes afloat as an active and previously undocumented process.

\section{SETTING}

The NIS is located inVictoria Land, East Antarctica (Fig. 1). Its grounding line (Fig. 2) is thought to run in a roughly south-north direction across Reeves Glacier, along the eastern side of Teall Nunatak (Frezzotti and others, 2000). The area of interest for this study is the branch of the Reeves Glacier flow which passes north of Teall Nunatak. In that section, surface velocities at the grounding line vary between $<50 \mathrm{~m} \mathrm{a}^{-1}$, near Teall Nunatak, and 100-150 $\mathrm{m} \mathrm{a}^{-1}$ further north, as illustrated in figure 6 of Frezzotti and others (2000). Radio-echo sounding data provided by the same authors show that ice thickness ranges from $120-150 \mathrm{~m}$, in the highly crevassed area located about halfway through, to $660 \mathrm{~m}$ further north. In addition to crevasses, rifts have opened near the grounding line. Some contain "islands" of continental ice chunks that have been frozen in place by the surrounding sea/marine ice (Fig. 3). From that point the shelf flows out into Terra Nova Bay for about $35 \mathrm{~km}$ to the front and is about $25 \mathrm{~km}$ across between Tarn Flat and Inexpressible Island. These two bedrock features together with the Northern Foothills laterally constrain the flow. The core was taken at $74^{\circ} 50.9^{\prime} \mathrm{S}, 162^{\circ} 51.3^{\prime} \mathrm{E}$, as close as was logistically possible to the grounding line, about $7.5 \mathrm{~km}$ downstream from it. This position was chosen in ice outcrops shown to be of sea-water origin by preliminary tests. Typical ice-flow horizontal velocities in the vicinity of the core site were measured by Frezzotti (1992) to be about $160 \mathrm{~m} \mathrm{a}^{-1}$. In the same paper, the author estimates that the ice shelf covers an area of approximately $1800 \mathrm{~km}^{2}$. Therefore, its area and average thickness make it a small to medium-sized ice shelf.

The phenomenon of lower strata of an ice shelf finding their way to the surface due to high ablation rates was first demonstrated by Gow and Epstein (1972). Souchez and others (1991) invoked such a process to explain the marineice nature of certain frontal sections of the Hells Gate Ice Shelf in the Terra Nova Bay area. Mass loss at the surface of an ice shelf could be induced by either melting and drainage or sublimation. The latter process is the one most likely to be prevalent in the NIS situation due to the intense and frequent katabatic wind activity. Wind velocity measurements are available from the weather station AWS 8931 (PAT) which is nearest to the core site, at $74^{\circ} 53^{\prime} \mathrm{S}, 163^{\circ} 00^{\prime} \mathrm{E}$ (Fig. 1). For the years 1989 and $1990,41.2 \%$ of the wind blew from the southwest, the direction of the Antarctic plateau, with wind speeds exceeding 28 knots $\left(52 \mathrm{~km} \mathrm{~h}^{-1}\right)$ for $>39 \%$ of the time (Baroni, 1996). This has undoubtedly contributed to enhanced surface ablation rates in the area, estimated by Frezzotti and others (2000) to be between $500 \pm 100$ and $400 \pm 80 \mathrm{~kg} \mathrm{~m}^{-2} \mathrm{a}^{-1}$ $\left(56 \pm 11\right.$ and $\left.44 \pm 9 \mathrm{~cm} \mathrm{a}^{-1}\right)$.

\section{ANALYTICAL TREATMENT}

Traditionally, the three principal parameters used to establish the marine-ice identity of a body of ice are crystallography, salinity and stable isotopes.

All work on the ice core was done in a cold room kept at $-25^{\circ} \mathrm{C}$. Vertical thin sections $7-10 \mathrm{~cm}$ long were continuously prepared along the entire $45 \mathrm{~m}$ of core length. Sampling for salinity measurements was done at the same frequency by cutting, at positions corresponding to the top of each thin section, a volume of ice necessary to produce about $15 \mathrm{~mL}$ of meltwater. This high sampling frequency has never been attempted in previous Antarctic marineice-core studies and it insures a much enhanced insight into the variability with depth of the ice properties and a better chance of detecting any interceding layers of different properties/origin.

Thin sections were viewed and photographed between crossed polarizers and then their crystal sizes were calculated using the linear intercept method (Tison and others, 1994). Conductivity was measured with a Tacussel CD810 conductimeter used with probe XE110 (cell constant $=2.01 \mathrm{~cm}$ ). During the conductivity measurements, the temperature of the melted samples was stabilized at $25.00^{\circ} \mathrm{C}$ by submerging their containers in a thermal bath. Since the temperature was not allowed to deviate in either direction by $>0.09^{\circ} \mathrm{C}$, the biggest error source was the error in the conductivity of the standard $\mathrm{KCl}$ solution used for calibrating the cell. Therefore, we estimate the error in the conductivity readings to be around $\pm 2.5 \%$.

Mass-spectrometry analysis of the oxygen isotope composition relative to Vienna Standard Mean Ocean Water (V-SMOW) was conducted on 99 samples chosen more or less regularly along the core length and guided in part by the salinity results. Measurement accuracy is $\pm 0.05 \%$.

\section{EVIDENCE}

The crystalline structure revealed by the thin sections is conspicuous by its complete lack of bubbles, which, for Antarctic ice, is a strong indication of its non-continental origin. Following the scheme outlined by Tison and others (1998) for the classification of marine-ice types, two subcategories can be used to describe most of the facies exhibited by the NIS core crystals. Few thin sections are observed to exclusively contain one of the facies, and for the most part the two facies are observed together in different proportions.

A first facies, which is attributed a frazil-ice origin, is made of small equigranular crystals with rounded boundaries that could therefore be identified as "granular orbicular" (Fig. 4a). One of the mechanisms listed by Weeks and Ackley (1982) for the formation of frazil ice is the adiabatic drop in pressure of rising water as a result of deep thermohaline circulation processes described above. Cores B13 (Oerter and others, 1992) and B15 (Oerter and others, 1994) also exhibit a granular facies, but some of the crystals show polygonal interlocking structure. According to Eicken and others (1994), this is probably inherited from the specific 


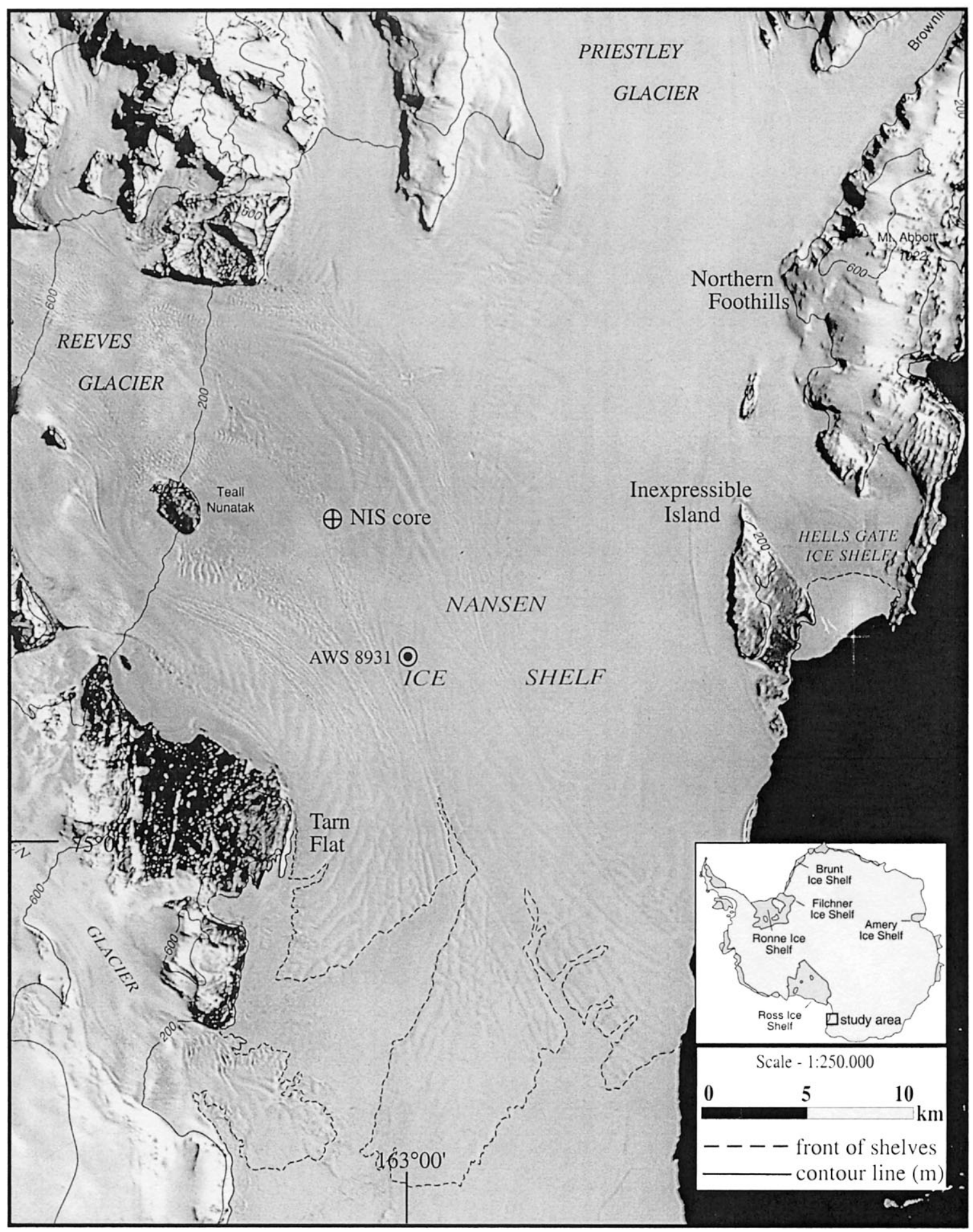

Fig. 1. Map of the NIS showing main surface features, the location of the drilling site and that of the meteorological station AWS 8931. Ice flows from the grounding line (located along the $200 \mathrm{~m}$ contour line around Teall Nunatak) to the front of the ice shelf indicated by the dashed line. The black area in the lower right corner of the picture is the open water of Terra Nova Bay. Background satellite image is taken from Borfecchia and Frezzotti (1991).

time/temperature (and perhaps deformation) growth history of the ice crystals as they accrete at the bottom of the ice shelf.

The second facies, which has not been reported for these other cores, is described by Tison and others (1998) as "string-lined" and presents a striking feature of the NIS core. Grains belonging to this latter category are noticeable for their elongation which shows a clear preference to occur in a vertical or near-vertical direction. Most of these crystals have a distinct rectangular aspect with an elongation factor of 2.5-6 and appear in thin sections throughout the core (Fig. 4b). This is in complete opposition to what has been observed in the B13 core. Eicken and others (1994) describe how most grains in the top part of B13 are elongated in a horizontal direction and how this elongation tends to disappear with depth. The occurrence of the string-lined facies in the NIS core is often accompanied by clear smallscale folding that has a wavelength and an amplitude both of the order of $4 \mathrm{~cm}$ (Fig. 4c). Folding tends to be absent from the core segment at 17-27 m depth.

Crystal-size variation with depth is plotted in Figure 4d. The mean NIS core crystal breadth is $1.7 \mathrm{~mm}$. If we were to use a rounded approximation, the corresponding average crystal cross-sectional area would be $2.7 \mathrm{~mm}^{2}$. This value is 


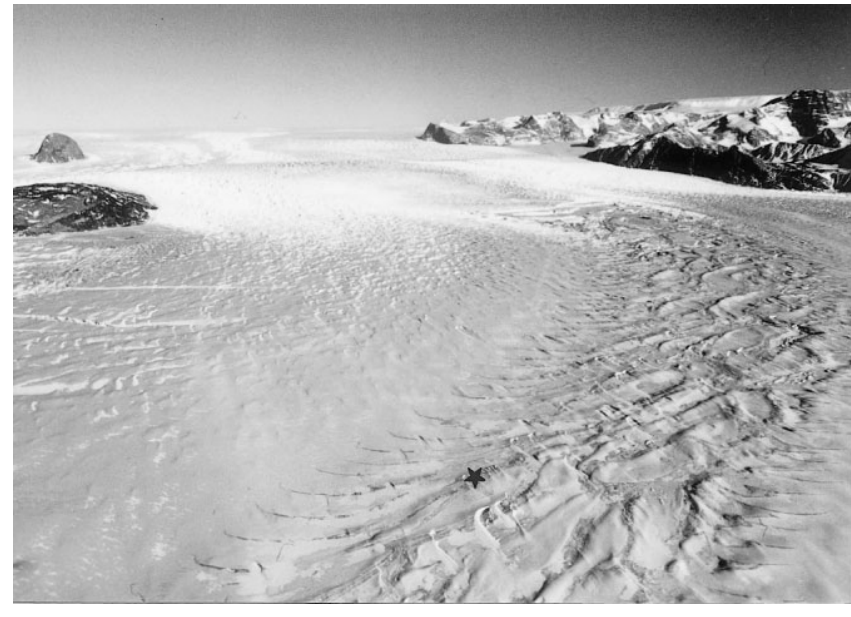

Fig. 2. Aerial photograph showing the morphological features of the NIS near its grounding line at the foot of Reeves Glacier. Approximate location of the drilling site is marked by a star. The larger rocky structure in the top left corner is Teall Nunatak. Beyond it is Reeves Glacier flowing towards the viewer. Notice how the marine ice in the crescent-shaped outcrops occurs in a series that extends all the way from the grounding line. A more detailed photograph of the source area of these structures is shown in Figure 3. At the coring site, marine ice was at the same level as meteoric ice at the surface of the ice shelf.

distinctly lower than those reported for the marine-ice sections of the other cores. While crystal cross-sectional areas were not mentioned for G1, Oerter and others (1994) report values that vary mostly between 5 and $60 \mathrm{~mm}^{2}$ for B13 and B15 crystals. Furthermore, with most NIS crystals having cross-sectional areas fluctuating between 1.1 and $3.8 \mathrm{~mm}^{2}$, they also exhibit a much more confined range than that of B13 and B15. NIS core crystal size shows a very weak tendency to increase with depth in the lower third of the core, as manifested by the smoothed (11-point running mean) profile of Figure 4d. The Bl3 core (Eicken and others, 1994), by contrast, shows a much clearer trend of increased crystal size with depth.

Both the quantitative values and the general qualitative behavior of the resulting conductivity profile with depth conform with those of marine ice. As can be seen from Figure $5 \mathrm{a}$, most conductivity readings are clustered in the interval between $80 \mu \mathrm{S} \mathrm{cm}^{-1}(0.035 \%$ salinity $)$ and $300 \mu \mathrm{S} \mathrm{cm}^{-1}$ $(0.145 \%$ o). These values are considerably lower than typical sea-ice salinities which extend between $3 \%$ and $25 \%$ (Weeks and Ackley, 1982). Even congelation ice which is thought to have formed beneath the Ross Ice Shelf does not exhibit any salinities below 2\%o (Zotikov and others, 1980). On the other hand, the NIS conductivity results do overlap the ranges of $40-200 \mu \mathrm{S} \mathrm{cm}^{-1}$ for B13 (Oerter and others, 1992) and 100$210 \mu \mathrm{S} \mathrm{cm}^{-1}$ for $\mathrm{Gl}$ (Morgan, 1972). Furthermore, the general trend of decreasing salinity with increasing depth echoes what has been observed in the above-cited studies. This can be seen from the smoothed (11-point running mean) profile of Figure 5a. On the other hand, it should be noted that the NIS core, with a maximum measured conductivity of $390 \mu \mathrm{S} \mathrm{cm}^{-1}$, generally exhibits higher salinities than $\mathrm{B} 13$ and G1. The top $0.4 \mathrm{~m}$ of marine ice in the $\mathrm{B} 15$ core exhibit conductivity values as high as $390 \mu \mathrm{S} \mathrm{cm}^{-1}$ (Oerter and others, 1994), but interaction with particle inclusions abundant in these layers could have occurred. Moreover, its conductivity profile rapidly drops back to a baseline value of around $40 \mu \mathrm{S} \mathrm{cm}^{-1}$, similar to that of B13 (Oerter and others,

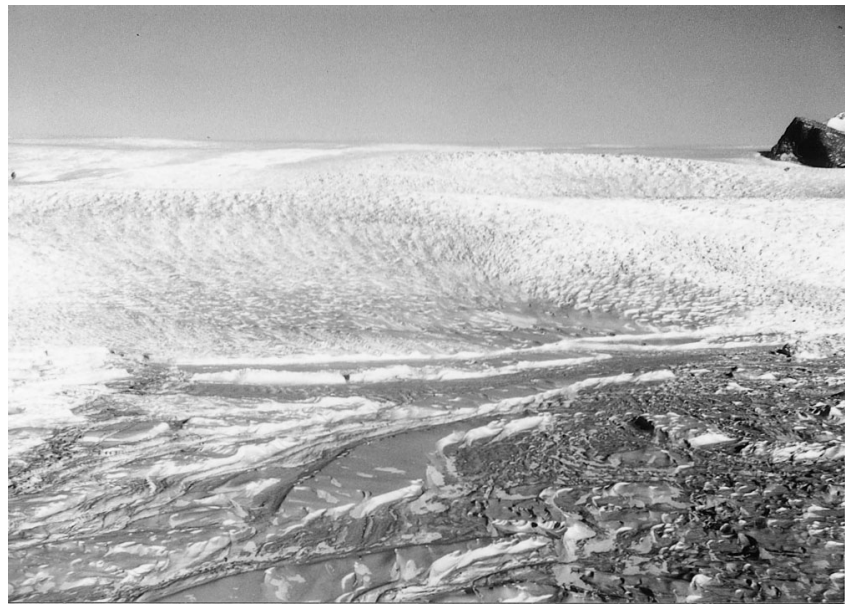

Fig. 3. Details of the fracture area at the origin of the flowline that passes through the location of the drilling site, $7.5 \mathrm{~km}$ downstream. The meteoric ice of Reeves Glacier (which is flowing towards the viewer) appears white in the upper half of the photograph, marine/sea ice is dark gray in the lower right area, and continental ice islands are visible as middlegray flat surfaces delimited by white cliffs.

1994). The NIS core, by contrast, has a conductivity baseline value that falls from around $140 \mu \mathrm{S} \mathrm{cm}^{-1}$ to $90 \mu \mathrm{S} \mathrm{cm}^{-1}$ with increasing depth (Fig. 5a). However, significant deviations from the baseline of the salinity/conductivity signal occur as "bumps", each extending over a few meters of depth along the profile. Furthermore, the high resolution of sampling has revealed the presence of smaller-scale (decimeter) fluctuations in the salinity signal which exceed the measurement error. The amplitude of this variation clearly increases with higher salinity values. Fluctuations have also been observed in sea ice, where Weeks and Ackley (1982) have emphasized the fact that even in the most homogeneous-seeming ice there is a small-scale, apparently random variation in the salinity.

The oxygen isotope composition results presented in Figure 5b do not show any clearly discernible trend with depth, nor do they show substantial variability (standard deviation $=0.09 \%$ ). The $\delta^{18} \mathrm{O}$ values cover a range between $+1.80 \%$ and $+2.37 \%$, with a mean value of $+2.12 \%$. This corresponds well with the slightly positive values reported for G1 by Morgan (1972), and the value of $+2 \%$ for B13 measured by Oerter and others (1992). Such slightly positive $\delta^{18} \mathrm{O}$ values are consistent with fractionation of sea water.

For comparison, $\delta^{18} \mathrm{O}$ values for continental ice samples from Hells Gate Ice Shelf, which is part of the NIS, cover a range between $-26 \%$ and $-32 \%$ (Ronveaux, 1992).

Plotting corresponding values in a $\delta^{18} \mathrm{O} /$ conductivity diagram (Fig. 6) does not result in a significant correlation $\left(r^{2}=0.07,99\right.$ points).

\section{DISGUSSION}

The evidence presented above strongly supports the idea that the NIS core is entirely composed of marine ice. This conclusion is reinforced by the comparison with B13, B15 and G1. It is excluded that this marine ice could have resulted from deep thermohaline circulation. Modeling work cited in the framework section predicts that melting prevails beneath an ice shelf near its grounding line. More specifically, Frezzotti and others (2000) calculated discharge fluxes across a flow channel located north of the crevassed 
a.

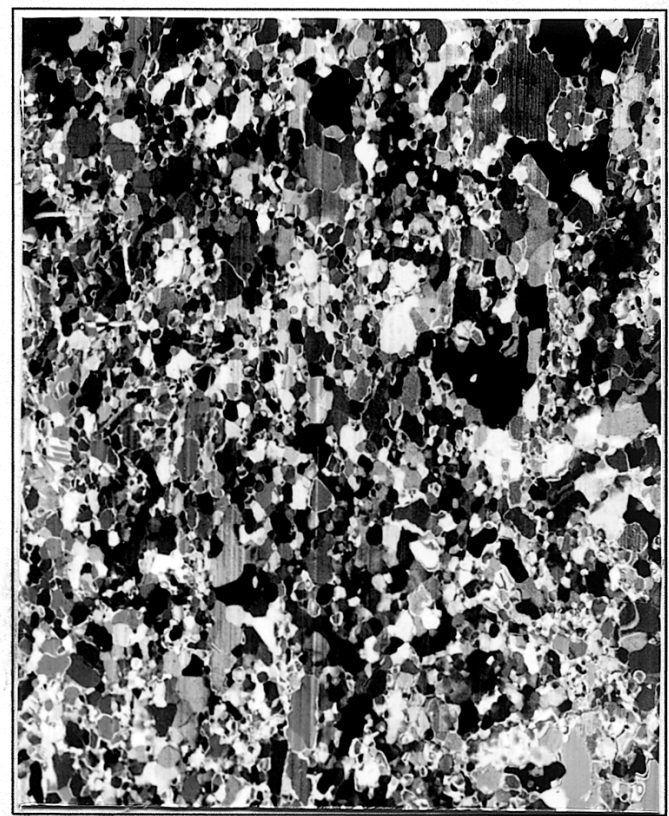

b.

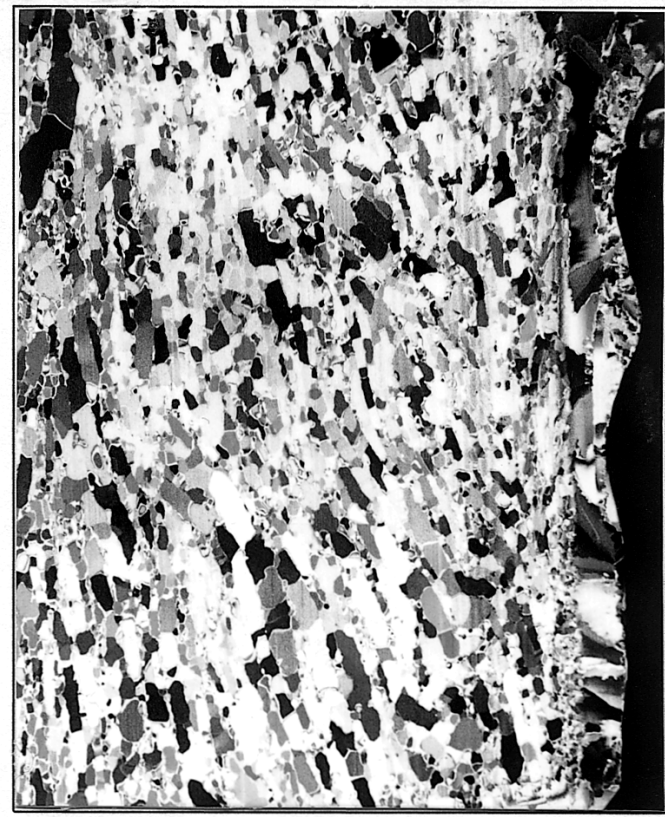

c.

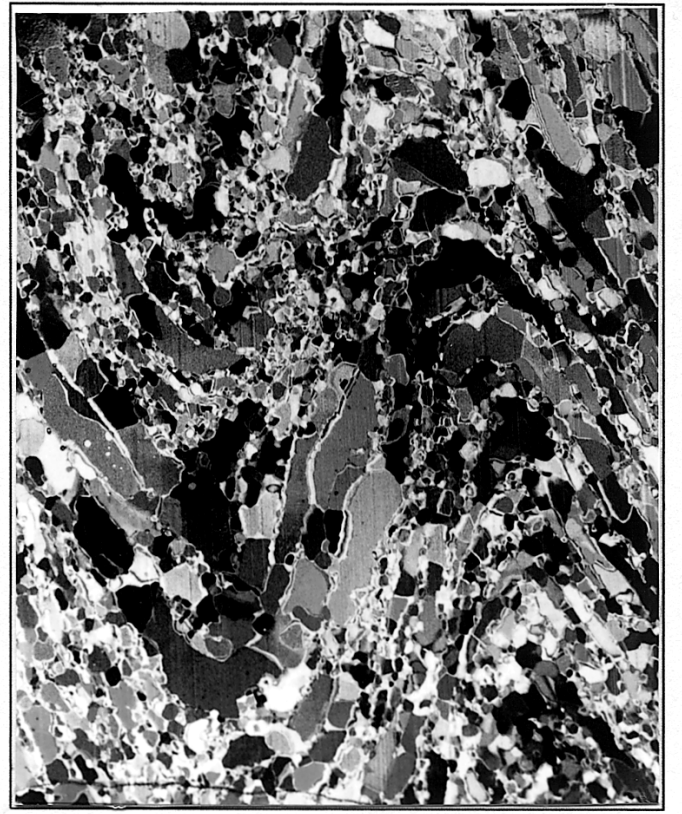

Average crystal cross-sectional area $\left(\mathrm{mm}^{2}\right)$

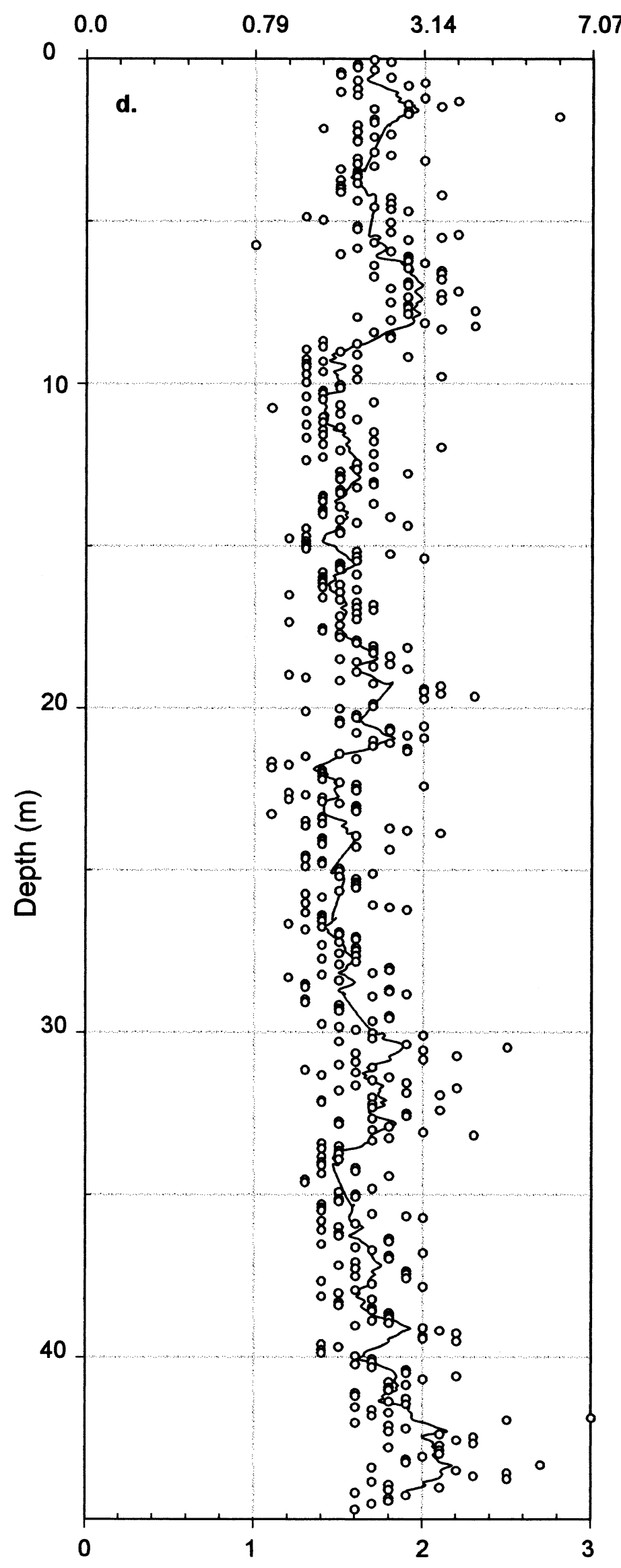

Average crystal breadth $(\mathrm{mm})$

Fig. 4. Crystallographic characteristics of the NIS core. Scale for photographs is shown on the bottom. (a) Granular/orbicular facies at $6.6 \mathrm{~m}$ depth; (b) string-lined facies at $16.6 \mathrm{~m}$ depth; (c) small-scale folding at $42.9 \mathrm{~m}$ depth; (d) profile of average crystal size with depth. Solid line in $(d)$ is an 11-point running mean. 

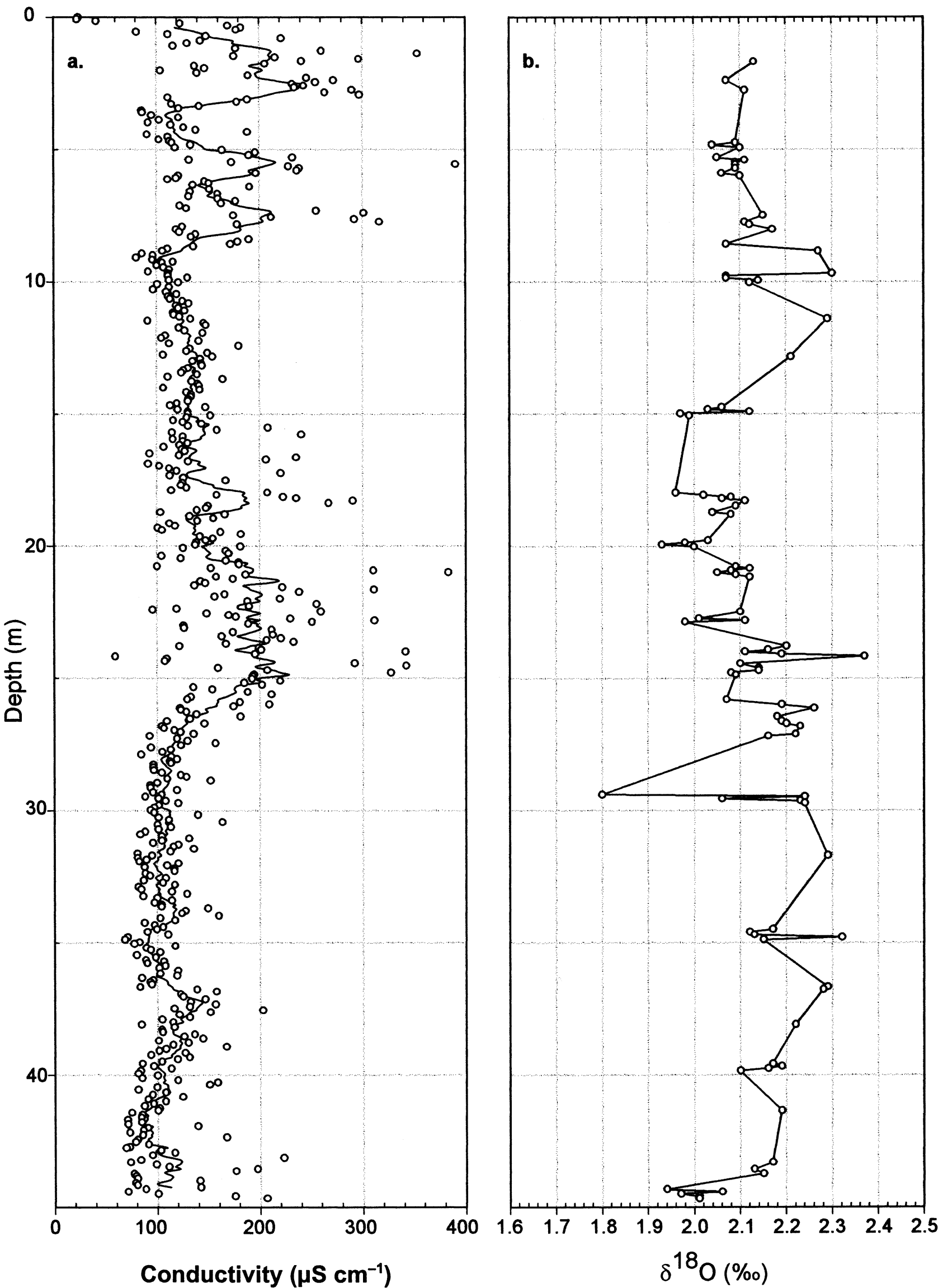

Fig. 5. Profiles of conductivity ( $a$ ) and $\delta^{18} O(b)$ for the NIS core. Solid line in $(a)$ is an 11-point running mean through the data points.

area where the marine ice originated. They deduced a mean net melting rate of the order of $0.26 \pm 0.90 \mathrm{~m} \mathrm{a}^{-1}$ between the NIS grounding line and $16 \mathrm{~km}$ down-flow, which well includes the core site. It is difficult to envisage marine ice accreting under such conditions. Furthermore, a very crude calculation would show that even if marine ice were to form near the grounding line at 120-660 m depth, it would never have the time necessary to reach the surface, given the prevalent flow velocities and ablation rates. This last point implies to us that perhaps marine ice is being formed nearer 


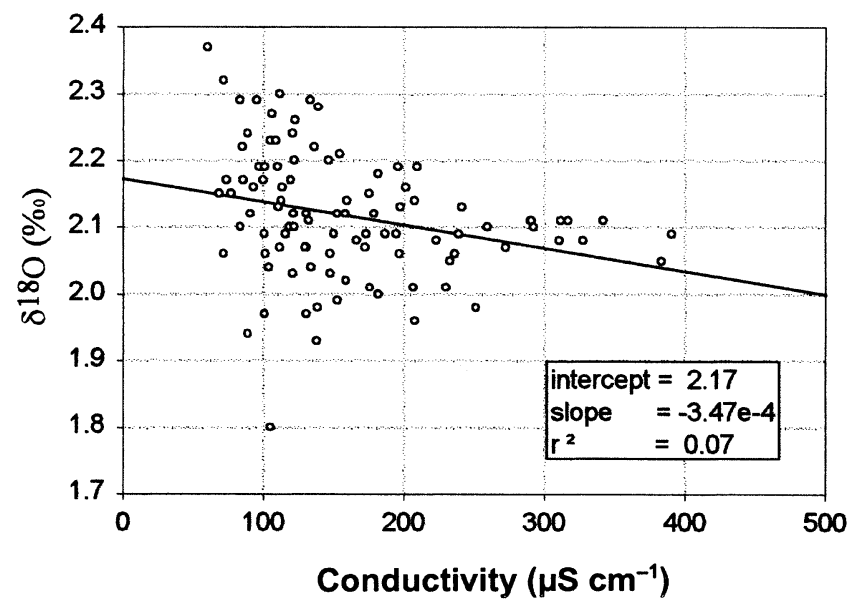

Fig. 6. $\delta^{18} \mathrm{O} /$ conductivity relation for 99 samples of the NIS core. Solid line represents linear regression through all points.

to the surface in some feature of the bottom topography of the ice shelf. Considering the geographical location near the grounding line of the study area which is cut by several rifts reaching all the way to the bottom of the ice shelf, and that the formation of such deep rifts often requires the presence of bottom crevasses reaching the surface, we regard basal crevasses as the most plausible explanation of our observations. Bottom crevasses are common features of Antarctic ice shelves. This has been demonstrated using radar sounding methods (e.g. Jezek and others, 1979). Shabtaie and Bentley (1982) describe how bottom crevasses vary widely in distribution and dimensions, with some reaching heights up to $250 \mathrm{~m}$ and bottom widths of $100 \mathrm{~m}$. Still more interestingly, Jezek and Bentley (1983) observed that bottom crevasses in the Ross Ice Shelf generally disappear from the radar record within $100 \mathrm{~km}$ downstream from their point of formation. This could be taken as a strong indication of bottom crevasses being filled with ice. We therefore propose that a large basal crevasse near the grounding line would provide a sheltered setting permitting the formation of marine ice in the midst of the basal ablation zone at the grounding line. A volume of Ice Shelf Water, which should become buoyant as a result of ice-shelf melting, would enter and ascend the crevasse, thus becoming supercooled. The basal crevasse would eventually, in part at least, become filled with marine ice in a manner similar to that described above for the formation, accumulation and subsequent consolidation of frazil ice under ice shelves. A similar local ice pump, but at the front of an ice shelf, has been hypothesized by Grosfeld and others (1998) to account for the occurrence of marine ice at the bottom of green icebergs thought to have originated in the former Grand Chasm of the Filchner Ice Shelf.

A complementary mechanism that could contribute to ice formation in open rifts and basal crevasses is the possibility of ice directly forming on the walls, as a result of heat conduction into the ice shelf. Such accretion would be relatively small in the lower parts of the crevasse, where conditions are comparable to those at the interface between the bottom of an ice shelf and the water (Jacobs and others, 1979). In the higher parts, especially shortly after the crevasse had opened, water would be in contact with ice that could be as cold as $-20^{\circ} \mathrm{C}$, so more significant direct accretion is certain to occur. However, it is possible that, with time, the presence of the crevasse itself would transform the thermal regime of the ice shelf surrounding it to one more similar to that at the ice-shelf/ocean interface, thus gradually reducing the magni- tude of congelation. Furthermore, in view of the generally large widths of rifts considered, congelation ice at the walls should only form a minor fraction of the total ice in the rift. Finally, in the particular case of the NIS core, the absence of ice with columnar texture, which is a distinctive sign of directfreezing origin, shows that none of the marine ice examined here formed directly at the walls of the crevasse.

Many of the underlined observed discrepancies between the NIS core and the marine-ice segments of the other cores considered actually support the hypothesis of a local ice pump being active in the suggested morphological configuration. This includes the relatively higher general salinity of the NIS core compared with B13, B15 and G1. In the situation we are proposing, higher salinity would be explained by the higher freezing rate of the interstitial water existing among the frazil crystals after their accumulation at the top of the water column and before their consolidation. In the case of a basal crevasse, the ambient waterfrazil mixture would be nearer to the surface, thus resulting in a more rapidly advancing freezing front and hence less efficient rejection of salt upon freezing. As the freezing front descends further away from the surface, the freezing rate would be reduced, resulting in better salt rejection and the observed trend of decreasing conductivity/salinity with depth. The direct relationship between the freezing rate and initial salt entrapment in sea ice was addressed by Weeks and Lofgren (1967) and further developed by Weeks and Ackley (1982). On the other hand, work on stableisotope fractionation in growing sea ice (Souchez and others, 1988; Eicken, 1998) showed an inverse relationship between the freezing rate and the $\delta^{18} \mathrm{O}$ or $\left.\delta \mathrm{D}\right)$ signal. The question might then be raised as to why the $\delta^{18} \mathrm{O}$ isotopic profile with depth (Fig. 5b) does not show a clear analogous influence by the freezing rate, nor does it show a clear inverse correlation with salinity (Fig. 6). This could be explained by the fact that frazil crystals themselves are almost completely desalinated, such that the salinity signal results only from the intergranular brine inclusions, while the isotopic signal reflects both contributions. Therefore, even if isotopic fractionation does occur in the brine inclusions due to the advancement of a freezing front, the resulting signal will be dominated by the overwhelming and unmodified contribution from the crystals. As for the isotopic signal of the crystals themselves, it is plausible that the temperature and pressure conditions necessary for the formation of frazil ice in the successive ascending water masses are regularly satisfied at a certain specific depth in the water column, thus producing frazil crystals with more or less the same isotopic enrichment, which would account for the rather weak variability of the NIS core isotopic signal. Eicken and others (1994), while noting the decreasing salinity with depth in the B13 core, exclude the advancement of a freezing front as an explanation of the salinity profile on the basis of thermodynamic constraints (conductive heat fluxes in the central Ronne Ice Shelf of the order of $0.1 \mathrm{~W} \mathrm{~m}^{-2}$ ) and of the "anomalously" low salt distribution coefficient $\left(k_{\text {eff }}<0.001\right)$ that would be needed to explain the observed salinity. The authors suggest that consolidation under the deviatoric buoyancy stress associated with the tens of meters of crystals accumulating beneath would lead to densification and expulsion of brine through fragmentation and settling of individual platelet crystals. However, in a companion paper (Tison and others, in press) we argue that both compaction and heat conduc- 


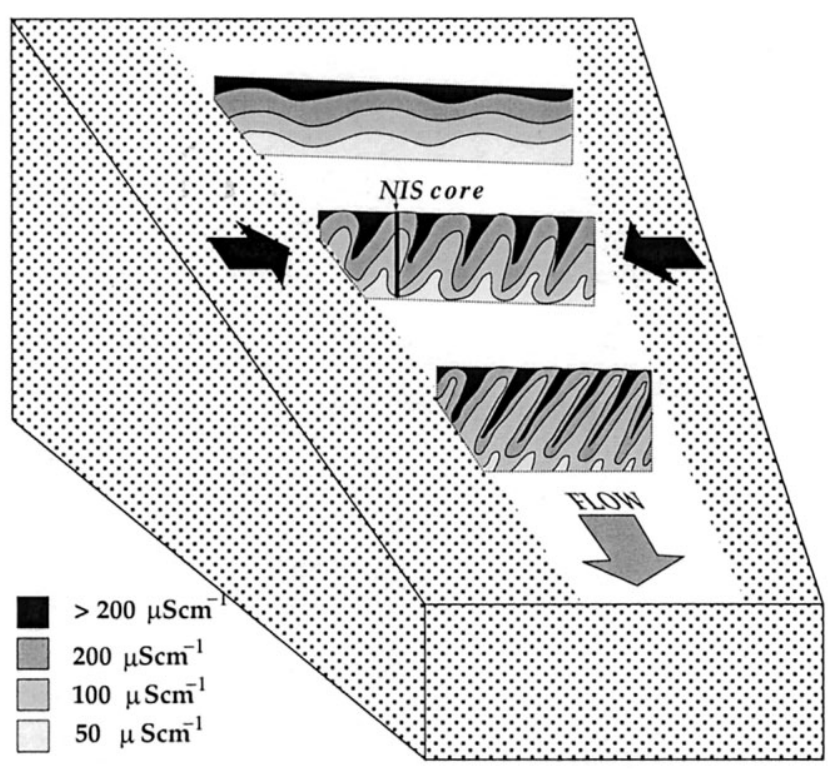

Fig. 7. Sketch of possible modification of the initial ice stratification due to lateral compression.

tion are probably needed to account for the chemical properties of marine ice. In the near-surface formation setting for marine ice being proposed in this paper, thermodynamic growth through the progressively slowing descent of a freezing front can certainly not be neglected.

Although initial salt entrapment and stable-isotope fractionation of the NIS marine ice have been determined by thermodynamic growth, subsequent reworking has clearly taken place, as attested by the salinity profile (Fig. 5a). It is the location of the core and its geomorphological context which provide at least two possible explanations for the presence of large-scale conductivity/salinity deviations from the baseline value: the first is related to the dynamically active core-site environment, which was described above to be a zone where different ice streams converge with different velocities and thickness, thus creating a situation where the ice is subjected to lateral compression. Such a stress configuration would fold the ice body and disturb the initial stratification as sketched in Figure 7 and as witnessed by the small-scale folding features in the core (Fig. 4c). The question remains why large-scale compression would only selectively affect the part of the core above $28 \mathrm{~m}$ and spare the lower part, as inferred from Figure 5a. The answer could be that large-scale folding has also occurred in the lower parts of the core but is not as visible because ice strata there are characterized by low salinity contrast. A second possible explanation is related to the core's location near the surface of the ice shelf, where its brine content could be affected by seasonal temperature changes. The resulting temperature gradients could produce brine-pocket migration (Hoekstra and others, 1965; Seidensticker, 1966), especially in the top few meters. The problem with this idea, however, is the slowness of the process (Weeks and Ackley, 1982; Eicken and others, 1994), associated with the fact that the seasonal temperature signal does not significantly affect the temperature profile below a certain depth (in continental ice, its amplitude would only be $5 \%$ of its surface value at $10.2 \mathrm{~m}$ (Paterson, 1994).

A basal crevasse, with its vertical spatial extension, would also account for the appearance of marine-ice layers on the ice-shelf surface despite proximity to the grounding line. This would also imply a relatively young age for the
NIS core ice (on the order of 50 years) compared to the hundreds of years estimated for the Filchner-Ronne cores by Eicken and others (1994). This would give the NIS grains less time to recrystallize, thus resulting in their relatively smaller sizes. On the other hand, the abundance of the string-lined facies and their vertical orientation could be due to grain recrystallization under the influence of a stress field applied by the walls of the crevasse. The presence of such stresses could in part be inferred from the appearance of folding in the core and its direction that suggest at least a horizontal component for the acting force.

It is worth noting that the proposed local ice-pump accretion process for marine ice in basal crevasses near the grounding line could easily be extended to the case of rifts opening in ice shelves, especially in the vicinity of ice rises, ice islands, on the side of large embayments and in the frontal regions of Antarctic shelves. Similarly, the process could occur in the regions of thinner ice that form between two converging ice streams (Tison and others, 1998, especially their fig. 3). Strong evidence for such occurrence is provided by the recent work of Fricker and others (in press). The authors infer the presence of two main bands of marine ice beneath the Amery Ice Shelf; both are clearly associated with the convergence points of ice streams.

To conclude this discussion, we consider a possible alternative explanation for the properties observed in the NIS core, namely, that a body of marine ice, originally formed in a bottom crevasse upstream from the core location, is detached, tilted and lodged in another crevasse downstream with an angle relative to its initial position, as has been observed for continental ice chunks. However, such a process does not account for the general tendency of conductivity to decrease with depth, nor for the presence of vertically aligned crystals along the whole length of the core. Furthermore, ongoing work on another $45 \mathrm{~m}$ core, located $24.5 \mathrm{~km}$ downstream from the grounding line, reveals properties similar to those described in this work. That the results of such a peculiar alternative process are observed at two different sampling locations is highly improbable.

\section{GONGLUSIONS}

We have demonstrated in this work that marine ice could be more readily recovered and studied by exploiting a combination of climatic (high surface ablation rates) and accretion locations (nearer to the surface in a basal crevasse or rift) for certain ice shelves. Recent ice--ocean modeling and fieldwork efforts are increasingly underlining the importance of marine-ice formation and accretion beneath Antarctic ice shelves. Improved comprehension of these processes is indispensable for accurate mass-balance estimations of ice shelves. We have shown that an important segment of the thickness of small to medium Antarctic shelves, at certain locations, could be formed of marine ice. These same shelves could be among the first to show signs of regional warming because of their smaller thermal inertia and proportionally more rapid reduction of contact surfaces with pinning points and embayment sides. The thermal properties of Antarctic ice shelves, and hence their heat exchange with the atmosphere and/or the ocean, could be modified if a larger proportion of their mass was composed of saline, bubble-free ice instead of fresh, bubbly continental ice. Most importantly perhaps, we have proposed a new possible setting for the formation of 
marine ice in the vicinity of the grounding line, where basal melting would normally prevail. In this context, a modeling effort and the analysis of another core recovered from the same ice shelf are progressing. Basal crevasses and rifts are common features near the grounding lines of ice shelves and in their frontal zones as precursors for iceberg calving. Studies of the dynamic stability of Antarctic ice shelves and their fragmentation mechanisms would benefit from better insight into the interaction of shelf rifts and crevasses with the ocean. Hughes (1983) explored the important role that these fracture features play in the disintegration of ice shelves, while Stephenson and Zwally (1989) discussed the stabilizing effect that might result from the filling of rifts with ice. Recently, Rignot and MacAyeal (1998) and MacAyeal and others (1998) have demonstrated how the dynamic properties of what they call the "ice melange" in open rifts do play an important role in the calving process at the front and in the overall stability of an ice shelf. According to these authors, the melange is composed of multi-year sea ice, ice-shelf fragments and windblown snow. It is quite plausible that the dynamic properties of the material filling the rifts, and its response to temperature variation, would be different if the ice was mainly composed of a homogeneous body of marine ice resulting from a process such as the one described in this paper rather than the mixture described by the above authors.

Although Antarctic rifts and basal crevasses are common, their overall area probably does not exceed a small fraction of that of a big ice shelf. However, they could make a disproportionate contribution if they occur at the grounding line, which is a point of compulsory passage for continental ice on its way to the sea. There, fractures could be filled with marine ice and exported downstream before new fractures form at the same point again and the process is repeated. A hint of such a sequence of events can be seen in Figure 2. Furthermore, as indicated by Corr and others (1995), considerable amounts of marine ice form at the confluence of individual ice streams that join together to form ice shelves. Such zones of steep lateral slopes are akin to a basal crevasse configuration and thus conducive to productive local ice pumps.

Finally, we believe that the high-resolution measurements presented in this work improve our perception of the variability patterns of ice-core properties with depth. Ongoing work on the three-dimensional variability of these signals should allow us to distinguish between the contribution to ice properties of the initial processes of consolidation and freezing and their subsequent modification through dynamic processes. Such an approach could help in revealing the mechanisms that lead to the comparatively very low salinities encountered in marine ice, still a subject of strong debate.

\section{ACKNOWLEDGEMENTS}

This paper is a contribution to the Belgian Antarctic Programme (Science Policy Office). The authors are greatly indebted to the "Programma Nazionale di Ricerce in Antartide" for their logistic support during the field campaign. The authors would also like to thank R. Souchez and R. Lorrain for informative discussions. The constructive criticism of the scientific editor, M. Lange, and two anonymous reviewers was much appreciated and helped improve the manuscript. J.-L. Tison is a Research Associate at the Belgian Science Foundation (FNRS).

\section{REFERENCES}

Baroni, C., ed. 1996. Mount Melbourne Quadrangle (Victoria Land). Siena, Museo Nazionale dell' Antartide. Ministerio dell' Università e della Ricerca Scientifica e Technologie. Programma Nazionale di Ricerce in Antartide. (Antarctic Geomorphological and Glaciological Series, scale 1:250,000.)

Bombosch, A. and A. Jenkins. 1995. Modeling the formation and deposition of frazil ice beneath Filchner-Ronne Ice Shelf. f. Geophys. Res., 100 (C4), 6983-6992.

Borfecchia, F. and M. Frezzotti. 1991. Satellite image mosaic of the Terra Nova Bay area (Victoria Land, Antarctica). Rome, Ente per le Nuove Tecnologie, l'Energia e l'Ambiente.

Corr, H., M. Popple and A. Robinson. 1995. Airborne radio echo investigations of a marine ice body. In Oerter, H., ed. Filchner-Ronne Ice Shelf Programme (FRISP). Report No. 9 (1995). Bremerhaven, Alfred Wegener Institute for Polar and Marine Research, 14-17.

Determann, J. and R. Gerdes. 1994. Melting and freezing beneath ice shelves: implications from a three-dimensional ocean-circulation model. Ann. Glaciol., 20, 413-419.

Eicken, H. 1998. Deriving modes and rates of ice growth in the Weddell Sea from microstructural, salinity and stable-isotope data. InJeffries, M. O., ed. Antarctic sea ice: physical processes, interactions and variability. Washington, DC, American Geophysical Union, 89-122. (Antarctic Research Series 74.)

Eicken, H., H. Oerter, H. Miller, W. Graf and J. Kipfstuhl. 1994. Textural characteristics and impurity content of meteoric and marine ice in the Ronne Ice Shelf, Antarctica. f. Glaciol., 40(135), 386-398.

Engelhardt, H. andJ. Determann. 1987. Borehole evidence for a thick layer of basal ice in the central Ronne Ice Shelf. Nature, 327(6120), 318-319.

Frezzotti, M. 1992. Fluctuations of ice tongues and ice shelves derived from satellite images in Terra Nova Bay area, Victoria Land, Antarctica. In Yoshida, Y., K. Kaminuma and K. Shiraishi, eds. Recent progress in Antartic earth sciences. Tokyo, Terra Scientific Publishing Co., 733-739.

Frezzotti, M., I.E. Tabacco and A. Zirizzotti. 2000. Ice discharge of eastern Dome $\mathrm{C}$ drainage area, Antarctica, determined from airborne radar survey and satellite image analysis. f. Glaciol., 46(153), 253-264.

Fricker, H.A., S. Popov, I. Allison and N. Young. In press. Distribution of marine ice under the Amery Ice Shelf, East Antarctica. Geophys. Res. Lett.

Gow, A.J. and S. Epstein. 1972. On the use of stable isotopes to trace the origins of ice in a floating ice tongue. 7. Geophys. Res., 77 (33), 6552-6557.

Grosfeld, K., H. H. Hellmer, M. Jonas, H. Sandhäger, M. Schulte and D. G. Vaughan. 1998. Marine ice beneath Filchner Ice Shelf: evidence from a multi-disciplinary approach. In Jacobs, S. S. and R. F. Weiss, eds. Ocean, ice and atmosphere: interactions at the Antarctic continental margin. Washington, DC, American Geophysical Union, 321-341. (Antarctic Research Series 75.)

Hellmer, H. H. and S. S. Jacobs. 1992. Ocean interactions with the base of Amery Ice Shelf, Antarctica. F. Geophys. Res., 97(C12), 20,305-20,317.

Hoekstra, P., T. E. Osterkamp andW. F. Weeks. 1965. The migration of liquid inclusions in single ice crystals. F. Geophys. Res., 70(20), 5035-5041.

Hughes, T. 1983. On the disintegration of ice shelves: the role of fracture. $\mathcal{F}$. Glaciol., 29 (101), 98-117.

Jacobs, S. S., A. L. Gordon and J. L. Ardai, Jr. 1979. Circulation and melting beneath the Ross Ice Shelf. Science, 203(4379), 439-443.

Jenkins, A. and A. Bombosch. 1995. Modeling the effects of frazil ice crystals on the dynamics and thermodynamics of ice shelf water plumes. $\mathcal{F}$. Geophys. Res., 100 (C4), 6967-6981.

Jezek, K. C. and C. R. Bentley. 1983. Field studies of bottom crevasses in the Ross Ice Shelf, Antarctica. f. Glaciol., 29 (101), 118-126.

Jezek, K. C., C. R. Bentley and J.W. Clough. 1979. Electromagnetic sounding of bottom crevasses on the Ross Ice Shelf, Antarctica. F. Glaciol., 24(90), 321-330.

Kipfstuhl, J., G. S. Dieckmann, H. Oerter, H. Hellmer and W. Graf. 1992. The origin of green icebergs in Antarctica. 7. Geophys. Res., 97(C12), 20,319-20,324.

Lewis, E. L. and R. G. Perkin. 1986. Ice pumps and their rates. 7. Geophys. Res., $91(\mathrm{Cl0}), 11,756-11,762$.

MacAyeal, D. R., E. Rignot and C. L. Hulbe. 1998. Ice-shelf dynamics near the front of the Filchner-Ronne Ice Shelf, Antarctica, revealed by SAR interferometry: model/interferogram comparison. f. Glaciol., 44(147), 419-428.

Morgan, V. I. 1972. Oxygen isotope evidence for bottom freezing on the Amery Ice Shelf. Nature, 238(5364), 393-394.

Oerter, H. and 6 others. 1992. Evidence for basal marine ice in the FilchnerRonne Ice Shelf. Nature, 358(6385), 399-401.

Oerter, H., H. Eicken, J. Kipfstuhl, H. Miller and W. Graf. 1994. Comparison between ice core $\mathrm{B} 13$ and B15. In Oerter, H., comp. Filchner-Ronne Ice Shelf Programme (FRISP). Report No. 7 (1994). Bremerhaven, Alfred Wegener Institute for Polar and Marine Research, 29-36.

Paterson, W. S. B. 1994. The physics of glaciers. Third edition. Oxford, etc., Elsevier. Rignot, E. and D. R. MacAyeal. 1998. Ice-shelf dynamics near the front of the 
Filchner-Ronne Ice Shelf, Antarctica, revealed by SAR interferometry. 7. Glaciol., 44(147), 405-418.

Robin, G. de Q. 1979. Formation, flow and disintegration of ice shelves. 7. Glaciol., 24(90), 259-271.

Ronveaux, D. 1992. The dynamics of a small Antarctic ice shelf as indicated by an ice composition study. (Ph.D. thesis, Université Libre de Bruxelles.)

Seidensticker, R. G. 1966. Comment on paper by P. Hoekstra, T. E. Osterkamp and W. F. Weeks, "The migration of liquid inclusions in single ice crystals". 7. Geophys. Res., 71 (8), 2180-2181.

Shabtaie, S. and C.R. Bentley. 1982. Tabular icebergs: implications from geophysical studies of ice shelves. F. Glaciol., 28(100), 413-430.

Souchez, R., J.-L. Tison and J. Jouzel. 1988. Deuterium concentration and growth rate of Antarctic first-year sea ice. Geophys. Res. Lett., 15(12), 1385-1388.

Souchez, R. and 7 others. 1991. Ice composition evidence of marine ice transfer along the bottom of a small Antarctic ice shelf. Geophys. Res. Lett., 18(5), 849-852.

Stephenson, S. N. and H. J. Zwally. 1989. Ice-shelf topography and structure determined using satellite-radar altimetry and Landsat imagery. Ann. Glaciol., 12, 162-169.

Tison, J.-L., T. Thorsteinsson, R. D. Lorrain and J. Kipfstuhl. 1994. Origin and development of textures and fabrics in basal ice at Summit, central Greenland. Earth Planet. Sci. Lett., 125, 421-437.
Tison, J.-L., R. D. Lorrain, A. Bouzette, M. Dini, A. Bondesan and M. Stiévenard. 1998. Linking landfast sea ice variability to marine ice accretion at Hells Gate Ice Shelf, Ross Sea. In Jeffries, M.O., ed. Antarctic sea ice: physical processes, interactions and variability. Washington, DC, American Geophysical Union, 375-407. (Antarctic Research Series 74.)

Tison, J.-L., A. Khazendar and E. Roulin. In press. A two-phase approach to the simulation of the combined isotope/salinity signal of marine ice. $\mathcal{F}$. Geophys. Res.

Warren, S. G., C. S. Roesler, V. I. Morgan, R. E. Brandt, I. D. Goodwin and I. Allison. 1993. Green icebergs formed by freezing of organic-rich seawater to the base of Antarctic ice shelves. 7. Geophys. Res., 98(C4), 6921-6928. (Correction: $98(\mathrm{Cl0}), 18,309$.

Weeks, W. F. and S. F. Ackley. 1982. The growth, structure and properties of sea ice. CRREL Monogr. 82-1.

Weeks, W. F. and G. Lofgren. 1967. The effective solute distribution coefficient during the freezing of $\mathrm{NaCl}$ solutions. In Öura, H., ed. Physics of snow and ice. Vol. 1, Part 1. Sapporo, Hokkaido University. Institute of Low Temperature Science, 579-597.

Zotikov, I. A., V. S. Zagorodnov and J.V. Raikovsky. 1980. Core drilling through the Ross Ice Shelf (Antarctica) confirmed basal freezing. Science, 207 (4438), 1463-1465.

MS received 20 December 1999 and accepted in revised form 8 May 2001 